\title{
Antinociceptive and bioactivity of leaves of Murraya paniculata (L.) Jack, Rutaceae
}

\author{
Shazid Md. Sharker, ${ }^{* 1}$ Israt Jahan Shahid, ${ }^{2}$ Md. Hasanuzzaman ${ }^{2}$
}

\author{
${ }^{1}$ Phytochemical and Pharmacognosy Laboratory, Department of Pharmacy, BGC Trust University Bangladesh, \\ "BGC Biddynagar" Chandanaish, Bangladesh \\ ${ }^{2}$ Pharmacy Discipline, Khulna University, Khulna, Bangladesh
}

\begin{abstract}
RESUMO: "Antinociceptiva e bioatividade das folhas de Murraya paniculata (L.) Jack, Rutaceae". Os resultados dos estudos de atividade antinociceptiva e toxicológicos do extrato etanólico de Murraya paniculata (L.) Jack, Rutaceae são relatados. O extrato (nas doses de 250 e $500 \mathrm{mg} / \mathrm{kg}$ ) produziu um alta atividade antinociceptiva na forma dose-dependente. $\mathrm{O}$ extrato também mostrou considerável toxicidade no teste de Artemia salina (DL50 = $32 \mu \mathrm{g} / \mathrm{mL}$ ).
\end{abstract}

Unitermos: Murraya paniculata, Rutaceae, contorções, analgesico, citotóxico.

\begin{abstract}
The results of antinociceptive and toxicological studies on the ethanol extract of the leaves of Murraya paniculata (L.) Jack, Rutaceae, are reported. The extract ( 250 and $500 \mathrm{mg} / \mathrm{kg}$ dosages) was found to produce a profound antinociceptive activity in a dose dependent manner. The extract showed considerable brine shrimp toxicity $\left(\mathrm{LD}_{50}=32 \mu \mathrm{g} / \mathrm{mL}\right)$.
\end{abstract}

Keywords: Murraya paniculata, Rutaceae, writhing, analgesic, cytotoxic.

\section{INTRODUCTION}

Murraya paniculata (L.) Jack, Rutaceae, grows commonly in the plain areas through the country (Ghani, 1998). The M. paniculata is a native and common throughout much of India, Burma, and Malacca and dry areas of Ceylon and is often grown in Thailand, Cambodia, South Vietnam and East Africa (Kirtikar \& Basu, 1987).

Previous phytochemical studies showed two new coumarins from M paniculata (Mesquita et al., 2008; Saied et al., 2008), the identification of dioxin and dioxin-like polychlorbiphenyls in plant tissues and contaminated soils (Jou et al., 2007). Isoflavonoids in the Rutaceae family was found in Fortunella obovats, M. paniculata and four in Citrus species (Lapcik et al., 2004). A new coumarin was also found in M paniculata (Choudhary et al., 2002). Structural features of a water soluble gum polysaccharide from Murraya paniculata in fruits was shown by Mondal et al. (2001). Kong et al. (1985) demonstrated the presence of a novel anti-implantation indole alkaloid.

Traditionally leaves of this plant are used for analgesia in different remotest plain lands of Bangladesh. Peoples usually use the leaves extract orally and reported alleviation of pain and felt soothe. This plant grows as a flowering plant and the flowers have sweet smell. No works have yet been done in this country and near topical area in regard of leave extract use for pain killing, so to say anti analgesic. Many studies have been done with the isolated compounds dried plant extracts. Two new coumarins have been isolated from Murraya paniculata and showed mild butyl cholinesterase inhibitory activity. But no antianalgesic has been reported as yet.

Keeping in mind the traditionally use of the plant (as per local report) has been chosen as to see any active single or combined principles responsible for alleviating pain associated with physiological or pathological condition.

\section{MATERIAL AND METHODS}

\section{Plant material}

For the present investigation the plant Murraya paniculata (L.) Jack, Rutaceae was collect from Khulna, Bangladesh in December 2007 and was identified by Bangaldesh National Herbarium, Mirpur, Dhaka. (Accession number- 32092) and a voucher specimen was also deposited there.

\section{Extract}

The powered plant material $(700 \mathrm{~g})$ was taken in of $80 \%$ ethanol $(1700 \mathrm{ml})$ for fifteen days. After evaporation to dryeness was found $26 \mathrm{~g}$ of the crude extract $(3.71 \%$ yield). 


\section{Animals}

Swiss albino mice (20-30 g) of either sex were obtained from the animal house of the International Centre for Diarrhoeal Disease and Research, Bangladesh (ICDDR, B). The animals were housed under standard laboratory conditions (relative humidity $55-65 \%$, room temperature $23 \pm 2{ }^{\circ} \mathrm{C}$ and $12 \mathrm{~h} \mathrm{light/dark} \mathrm{cycle).} \mathrm{The} \mathrm{animals} \mathrm{were} \mathrm{fed}$ with standard diet and water ad libitum. The University Animal Research Ethical Committee approved the experimental protocol.

\section{Antinociceptive activity}

The acetic acid induced writhing method is an antinociceptive behavioral observation assessment method that demonstrates a noxious stimulation in mice. The test consists of injecting the $0.7 \%$ acetic acid solution intraperitoneal and then observing the animal for specific contraction of body referred as 'writhing'. A comparison of writhing is made between control, positive control (Diclofenac sodium), and test sample. Control and positive control (Diclofenac sodium) and test sample are given orally 30 min prior to acetic acid injection. If the sample possesses analgesic activity, the animal that received the sample will give lower number of writhing than the control, i.e. the sample having analgesic activity to inhibit writhing (Whittle, 1964).

\section{Cytotoxic activity of Murraya paniculata}

The brine shrimps used were obtained by hatching $5 \mathrm{mg}$ of eggs of Artemia salina in natural seawater after incubatedion at about $29^{\circ} \mathrm{C}$ for $48 \mathrm{~h}$. The larvae (nauplii) were allowed another $48 \mathrm{~h}$ in seawater to ensure survival and maturity before use. Five dose of plant extract (20, $40,60,80,100,120$ and $140 \mu \mathrm{g} / \mathrm{ml})$ in $5 \%$ DMSO and $/$ or seawater was tested. Each extract preparation was dispensed into clean test tubes in $10 \mu \mathrm{l} / \mathrm{ml}$ for control; same procedure was followed except test samples. After marking the test tubes properly, ten living shrimps were added to each of the eighteen vials with the help of a Pasteur pipette (Meyer et al., 1982). The test tube containing the sample and control were then incubated at $29^{\circ} \mathrm{C}$ for $24 \mathrm{~h}$ in a water bath, after which each tube was examined and the surviving brine shrimps counted and recorded. From this, the percentage of mortality was calculated at each concentration.

\section{RESULTS AND DISCUSSION}

The extract of the leaves of Murraya paniculata produced significant antinociceptive activity, and writhing protecting in a dose dependent manner. Table 1 showed the effect of the ethanol extract of Murraya paniculata on acetic acid induced writhing in mice. At the dose of 250 and $500 \mathrm{mg} / \mathrm{kg}$ of body weight, the extract produced about 26.67 and $66.67 \%$ writhing inhibition in test animals, respectively. The results were statistically significant $(p<0.005, p<0.001)$ and were comparable to the standard drug diclofenac sodium, which showed $82.70 \%$ writhing inhibition at the dose of $25 \mathrm{mg} / \mathrm{kg}(\mathrm{p}<0.001)$.

Ethanol was used which has a wide range of solubility in both polar and non-polar region. To avoid any solvent effect on the experimental animals, the solvent was evaporated completely to dryness.

Antinociceptive activity of the ethanol extract of Murraya paniculata was tested by acetic acid induced writhing model in mice. Acetic acid induced writhing model represents pain sensation by triggering localized inflammatory response. Acetic acid, which is used to induce writhing, causes algesia by liberation of endogenous substances, which in turn excite the pain nerve endings (Taesotikul et al., 2003). Increased levels of $\mathrm{PGE}_{2}$ and $\mathrm{PGF}_{2 \alpha}$ in the peritoneal fluid have been reported to be responsible for pain sensation caused by intraperitoneal administration of acetic acid (Derardt et al., 1980). The ethanol extract of Murraya paniculata produced significant writhing inhibition comparable to the standard drug diclofenac sodium (Table 1). On the basis of this result it can be concluded that the ethanol extract of Murraya paniculata might possess analgesic activity.

Using brine shrimp lethality bioassay tested the cytotoxic activity of the ethanol extract of leaves of Murraya paniculata. It is a recent development in the bioassay for the bioactive compounds. Brine shrimp lethality bioassay indicates cytotoxicity as well as a wide range of pharmacological activities, such as antimicrobial, pesticidal, antitumor etc (Anderson et al., 1988). The extract was found to show potent activity against the brine shrimp nauplii. Therefore the positive response obtained in the assay suggests that the extract may contain antitumor, antibacterial or pesticidal compounds.

Table 1. Effect of ethanol extract of Murraya paniculata on acetic acid induced writhing in mice.

\begin{tabular}{ccc}
\hline Animal group/treatment & $\begin{array}{c}\text { Number of writhes } \\
\text { (\% writhing) }\end{array}$ & $\begin{array}{c}\text { Inhibition } \\
(\%)\end{array}$ \\
\hline C o n t r o 1 & $45 \pm 1.52$ & -- \\
$1 \%$ tween-80 in water 10 ml/Kg, p.o & $(100)$ & \\
Positive control & $7.8 \pm 1.8^{\mathrm{a}}$ & 82.7 \\
Diclofenac sodium $25 \mathrm{mg} / \mathrm{kg}$, p.o. & $(17.30)$ & \\
Test group-I & $33 \pm 1.91^{\mathrm{b}}$ & 26.67 \\
Ethanol extract 250 mg/kg, p.o. & $(73.33)$ & \\
Test group-II & $15 \pm 1.94^{\mathrm{a}}$ & 66.67 \\
Ethanol extract 500 $\mathrm{mg} / \mathrm{kg}$, p.o. & $(33.33)$ & \\
\hline
\end{tabular}

Values are expressed as mean \pm S.E.M $(n=5) ; *$, $\mathrm{p}$ value were determined using student t-test, $\mathrm{a}>0.001, \mathrm{~b}>0.005$ vs. control; $\%$, percentage. p.o., per oral. 
Table 2. Biological activity of ethanol extract of Murraya paniculata on Artemia salina test.

\begin{tabular}{c|c|c|c|c|c|c|c|c|}
\hline Conc. $(\mu \mathrm{g} / \mathrm{ml})$ & Log (Conc.) & $\mathrm{T}-1$ & $\mathrm{~T}-2$ & $\begin{array}{c}\text { Average number of } \\
\text { alive shrimp (sample) }\end{array}$ & $\begin{array}{c}\text { Average number of } \\
\text { alive shrimp (Control) }\end{array}$ & $\%_{\text {of mortality }}$ & $\begin{array}{c}\mathrm{LC}_{50} \\
(\mu \mathrm{g} / \mathrm{ml})\end{array}$ & $\begin{array}{c}\mathrm{LC}_{90} \\
(\mu \mathrm{g} / \mathrm{ml})\end{array}$ \\
\hline 5 & 0.69 & 9 & 8 & 8.5 & 9.5 & 15 & \\
\hline 10 & 1 & 7 & 8 & 7.5 & 9 & 25 & \\
\hline 20 & 1.30 & 6 & 6 & 6 & 8.5 & 40 & 35 \\
\hline 40 & 1.60 & 5 & 4 & 4.5 & 9.5 & 75 & \\
\hline 80 & 1.90 & 3 & 2 & 2.5 & 8 & 95 & \\
\hline
\end{tabular}

\section{CONCLUSION}

In conclusion, it could be suggested that the crude ethanol extract of Murraya paniculata may posses' analgesic and cytotoxic activities. However, further studies are necessary to find out the active principles responsible for these activities.

\section{REFERENCES}

Anderson JE, Chang CJ, McLaughlin JL 1988. Bioactive components of Allamanda schottii. J Nat Prod 51: 307308.

Choudhary MI, Azizuddin Khalid A, Sultani SZ, Atta-ur-Rahman 2002. A new coumarin from Murraya paniculata. Planta Med 69: 882.

Derardt R, Jougney S, Delevalcee F, Falhout M 1980. Release of prostaglandins $\mathrm{E}$ and $\mathrm{F}$ in an algogenic reaction and its inhibition. Eur J Pharmacol 51: 17-24.

Ghani A 1998. Medicinal Plants of Bangladesh. The Asiatic Society of Bangladesh, Dhaka, Bangladesh, 1st ed. pp. 3-17, 215, 323.

Jou JJ, Chung JC, Weng YM, Liaw SL, Wang MK 2007. Identification of dioxin and dioxin-like polychlorbiphenyls in plant tissues and contaminated soils. J Hazard Mater 149: 174-179.

Kirtikar KR, Basu BD 1987. Indian Medicinal Plants. $2^{\text {nd }}$ ed. International Book Distributors, India. p. 1952-1953.

Kong YC, Ng KH, Wat KH, Wong A, Saxena IF, Cheng KF, But PP, Chang HT 1985. Yuehchukene, a novel antiimplantation indole alkaloid from Murraya paniculata. Planta Med 51: 304-307.

Lapcik O, Klejdus B, Davidová M, Kokoska L, Kubán V, Moravcová J 2004. Isoflavonoids in the Rutaceae family: 1. Fortunella obovata, Murraya paniculata and four Citrus species. Phytochem Anal 15: 293-239.

Mesquita SG, Martinez MF, Romoff P, Fávero OA, Lieber SR, Lago JHG 2008. Constituintes químicos das folhas de Murraya paniculata (Rutaceae). Rev Bras Farmacogn 18: 563-568.

Meyer BN, Ferrigni NR, Putnam JB, Jacobsen LB, Nichols DE, McLaughlin JL 1982. Brine shrimp: a convenient general bioassay for active plant constituents. Planta Med 45: 31-34.

Mondal SK, Ray B, Ghosal PK, Teleman A, Vuorinen T 2001. Structural features of a water soluble gum polysaccharide from Murraya paniculata fruits. Int J Biol Macromol 29: 169-174.

Saied S, Nizami SS, Anis I 2008. Two new coumarins from Murraya paniculata. J Asian Nat Prod Res 10: 515-519.

Taesotikul T, Panthong A, Kanjanapothi D, Verpoorte R, Scheffer JJC 2003. Anti-inflammatory, anti-pyretic and antinoceptive activities of Tabernaemontana pandacaqui. $J$ Ethnopharmacol 84: 31-35.

Whittle BA 1964. The use of changes in capillary permeability in mice to distinguish between narcotic and non-narcotic analgesics. Br J Pharmacol Chemother 22: 246-253. 